Research Article

\title{
Investigating the Effect of Oil Revenue Shocks on Business Cycles and the Synchronism of Cycles with Selected OECD Countries
}

\author{
Reza Ashraf Ganjoei $(\mathbb{D}$, Nouralah Salehi Asfiji $(\mathbb{D}$, and Esmat Olad Shanbeh \\ Department of Economics, Faculty of Management and Economics, Shahid Bahonar University of Kerman, Kerman, Iran \\ Correspondence should be addressed to Nouralah Salehi Asfiji; salehinoor@gmail.com
}

Received 11 February 2021; Accepted 19 May 2021; Published 31 May 2021

Academic Editor: Benjamin Ivorra

Copyright (C) 2021 Reza Ashraf Ganjoei et al. This is an open access article distributed under the Creative Commons Attribution License, which permits unrestricted use, distribution, and reproduction in any medium, provided the original work is properly cited.

\begin{abstract}
The effect of temporary and permanent shocks of oil revenues on the concurrence of trade cycles between Iran and selected OECD countries has been investigated using the data series of the period 1985-2019. For this purpose, first, business cycles and temporary and permanent shocks of oil revenues are extracted using Hodrick-Prescott (HP) filter and Blanchard-Quah technique, respectively. Then, the relationship between business cycles and model-independent variables is evaluated by the ARDL method. The results show that the main cause of business cycle fluctuations is temporary shocks to oil revenues, also, government expenditure variables and permanent and temporary shocks to oil revenues in the short and long term have a negative and significant effect on business cycles, and the exchange rate variable has a positive and significant effect on business cycles. Estimation of business cycle synchronization index shows that Belgium, Germany, Greece, Japan, Spain, and Turkey have had business cycles synchronization with Iran. And Germany with a correlation coefficient of 0.42 has the most synchronization of business cycles with Iran.
\end{abstract}

\section{Introduction}

Gross domestic product (GDP) is one of the most important macroeconomic performance indicators because it shows the size of a country's economy and its production capacity. Since the most important goal of economists is to prevent fluctuations and instability of the economy, and examining the factors affecting GDP fluctuations is very important for economic planning there is a fundamental need to study business cycles. Bronze and Mitchell [1] consider business cycles as a kind of irregular fluctuations in the macroeconomic activities of countries, which are mainly created and organized based on the market economy and the activities of enterprises. Accordingly, a period of prosperity begins almost simultaneously in most economic activities, followed by recession and contraction, which slows down economic activity. After this recession, recovery occurs, and after that recession occurs; these changes are repeated many times, but they do not necessarily have a regular periodic state. Long and Plosser [2] consider business cycles as regular fluctuating patterns of macroeconomic variables such as production, consumption, investment, employment, and prices, which include recessions and booms around the path of long-term economic growth, the so-called trend. The most common concept of business cycles is the definition of Lucas [3]. He defines business cycles as the recurring deviations of real GDP around its long-term trend. It should be noted that business cycles of fluctuations are not a specific part or part of the economy, but the set of economic movements or the movement of GDP. Dornbush et al. [4] consider business cycles as regular fluctuations in economic activity and stagnation around economic growth. According to them, business cycles are regular fluctuations in macroeconomic activities. Hence, any observed fluctuations cannot be called business cycles.

Therefore, the cause of business cycles can be monetary and fiscal policies, changes in consumer demand and investment, trade shocks such as shocks caused by changes in oil prices, and technology. As the oil sector in Iran plays a major role in providing the energy needed to implement 
development and economic growth programs, as well as meeting the foreign exchange needs of these programs, it is considered the motive force of the national economy. Oil revenues are a direct function of two variables, the world price of crude oil and the amount of its extraction (export), and the result of their together change.

The amount of variable price for all producers and exporters of crude oil, including Iran, is almost a function of global supply and demand of crude oil, but the amount of production and export is within the capabilities and shortterm and long-term decisions of each producer. At present, the only factor determining the volume of Iran's oil revenues is its world price, which is beyond the control of Iran and all OPEC member countries. Therefore, oil-exporting governments, including Iran, are not able to optimize their oil revenues and are always exposed to fluctuations in oil revenues out of control. The main purpose of this study is to investigate the effect of temporary and permanent shocks of oil revenues on Iran's business cycles and the synchronization of cycles with selected OECD countries using the Hodrick-Prescott (HP) filter. Business cycles are extracted using the Blanchard-Quah technique of temporary and permanent shocks to oil revenues. Then the relationship between business cycles and model-independent variables is evaluated and analyzed by the ARDL method. The results of this study show that the main cause of fluctuations in business cycles is temporary shocks oil revenues, so that, in all periods, temporary shocks in oil revenues have had the largest share in creating fluctuations in business cycles. Permanent and temporary shocks of oil revenues have a negative impact on the flow of business cycles, so that the increase of permanent and temporary shocks of oil revenues causes a recession in the economy. The impact of government spending on the Iranian economy on the formation of business cycles is negative, so that increasing government spending leads the economy to recession because increasing government spending reduces private sector investment in the country. The exchange rate variable is directly related to business cycles; that is, with the increase of the exchange rate, the economy moves towards prosperity, and with its decrease, the economy moves towards recession.

The rest of this research is organized as follows. In Section 2, we present a theoretical background and related literature. Section 3 presents the econometric methods. Section 4 presents estimation of the original model and analysis. In Section 5, the conclusion is presented.

\section{Theoretical Background and Related Literature}

This section reviews studies related to oil revenue shocks, business cycles, and business cycle synchronization. Hamilton [5] showed that large negative shocks can be characterized by modeling recessions with discontinuous shocks and modeling their occurrence as a Markov process. Kydland and Prescott [6] describe the business cycles of the American economy as a nonmonetary phenomenon. Alper [7] describes the business cycles of the Turkish economy as nonmonetary phenomena. Stock and Watson [8] show that
US government nondefense spending has nothing to do with business cycles. Rana [9] uses the development of a study by Xin and Wang [10] to examine the effect of trade intensity on the synchronization of business cycles among East Asian countries in the areas of trade, monetary, and financial investment over time 1993-2004.

In this study, three methods, simple correlation, VAR, and panel data, using the gravity model have been used. The results indicate that intraindustrial trade compared to interindustrial trade is a more important factor in explaining the mobility of trade cycles between East Asian countries. This result is important because the concurrence of business cycles is a prerequisite for the formation of a monetary union and a common monetary system. Inklaar et al. [11] in a study examined the relationship between the intensity of bilateral trade and the concurrence of business cycles. For this purpose, three synchronization patterns of business cycles, gravity pattern, production structure pattern, and correlation of business cycles have been estimated. The results of this paper, which was conducted for 21 OECD countries in the period 1970-1970, show that the intensity of bilateral trade has a positive effect on the synchronization of trade cycles. Mendoza and Vera [12] examined the asymmetric effects of oil shocks on Venezuela's economy as an oil exporter during the period 1984-2008. In this study, they used the methods of Mork [13] and Hamilton [5] to distinguish between positive and negative oil shocks. The results of this study show that oil shocks have a positive and significant effect on production growth in this country. Also, the impact of positive oil shocks on the level of production is more than its negative shocks, which indicates the asymmetric effects of oil shocks on the level of production in this country. Hsu et al. [14] examined the effect of foreign direct investment, trade, and production specialization on the synchronization of business cycles in 77 developed countries during the years 1988-2002 using the 3SLS method. The results show that foreign direct investment is an important channel for the international transfer of business cycles and has a positive effect on the synchronization of business cycles. Also, the dissimilarity of the industrial structure is positively related to trade and negatively related to foreign direct investment, so that the dissimilarity of the industrial structure has an indirect and negative effect on concurrence. Jahadi and Elmi [15] have studied the asymmetric effects of oil shocks on the economic growth of OPEC and OECD countries in the form of vector autoregression (VAR) model. In this study, they used the HP filter to distinguish between positive and negative oil shocks. The results of this study show that oil shocks in the countries of both groups will have detrimental effects, although the amount of these effects is different in the countries of these two groups. Huseynov and Ahmadov [16] examined the business cycle in oil-exporting countries. The countries surveyed in this study are Algeria, Angola, Azerbaijan, Iran, Kazakhstan, Kuwait, Nigeria, Norway, Oman, Russia, Saudi Arabia, the United Arab Emirates, and Venezuela. In this study, the variables affecting business cycles, GDP, investment, government spending, imports, exports, exchange rates, liquidity, and inflation are listed. Empirical analysis shows that oil price shocks cannot be the 
main source of economic fluctuations in these countries. Also, with the increase of global economic integration, the role of oil as the main source of economic fluctuations in oilexporting countries has decreased. In their study, Fedderke and Mengisteab [17] examined business cycles in South Africa for the period 1960 to 2015. They use the HP filter and the Kalman filter. The results show that the potential growth rate during the period averaged between 1.9 and 2.3 percent, with the lowest growth related to the mining and industrial sectors and the highest related to the service sector.

2.1. Business Cycles and Synchronization Cycles. In the field of business cycles, many studies have been done on identifying shocks and how they are formed and propagated.

The most authentic definition in this field is the scientific definition of Burns and Mitchell. The definition is as follows: "Business cycles are a type of fluctuation that occurs in the overall economic activities of countries that have based their economies mainly on market economics or free enterprise activity." A business cycle involves a period of prosperity that occurs almost simultaneously in many economic activities. After a while, it is accompanied by a vertical and contractionary recession in economic activities, which after a while enters another phase of prosperity and the next cycle. This sequence of changes is repetitive but does not follow a specific periodicity, and in this respect varies in terms of the duration of business cycles from one year to 10 or 12 years. Which cannot be divided into short cycles with similar characteristics and almost similar fluctuations. In general, business cycles do not have a fixed pattern. Fluctuations in production can fluctuate consumption, investment, government spending, and net exports, which are components of production. These components can move in the direction of the cycles or in the opposite direction. Periods do not change suddenly, which is called durability. The concept of business cycle synchronicity was first coined in 1946 by Burns and Mitchell. They believe that the concurrence of business cycles occurs when the rotation points of reference cycles are created approximately at the same time.

To measure the synchronicity of business cycles according to empirical studies such as Frankel and Rose, Calderon, Shin and Wang, Inclar, and others, Ekin and Shaygan have detrended the GDP correlation coefficient criterion. The correlation coefficient for countries $i$ and $j$ is calculated according to

$$
\operatorname{corr}\left(y_{i}^{c}, y_{j}^{c}\right)=\frac{\operatorname{cov}\left(y_{i}^{c}, y_{j}^{c}\right)}{\sqrt{\operatorname{var}\left(y_{i}^{c}\right) \operatorname{var}\left(y_{j}^{c}\right)}} .
$$

The expression $y^{c}$ is the logarithm of the detrended GDP based on the value of GDP at constant prices in dollars. A positive sign of correlation coefficient indicates the synchronization of business cycles between the two countries $i$ and $j$ and a negative coefficient indicates the nonsynchronization of business cycles between the two countries $i$ and $j$.
2.2. Extract Business Cycles. Extraction of business cycles is done using filtering tools that include Kalman and HP filters. In this research, the HP filter has been used.

2.2.1. Hadrick Prescott Filter. In this section, we will learn about the HP filter as a tool for extracting the business cycle. This method was first used in the real business cycle literature but gradually expanded its scope to compare business cycles between countries, so that since 1981, this filter was first introduced by HP. So far it has become a standard way to detrend time series. In particular, in order to identify the revealed facts of business cycles, this filter has been widely used in business cycle studies. The problem of Hedrick and Prescott filters is obtained by minimizing equation (2):

$$
\begin{aligned}
j= & \sum_{t-1}^{T}\left(X_{t}-\tau_{X, t}\right)^{2} \\
& +\alpha \sum_{t-2}^{T-1}\left[\left(\tau_{X, t+1}-\tau_{X, T}\right)-\left(\tau_{X, t}-\tau_{X, T-1}\right)\right]^{2} .
\end{aligned}
$$

The first component in equation (2) is the sum of the deviations of the time series variable $X_{t}$ from its trend $(T) . \alpha$ determines the degree of smoothness of the process component so that the larger $\alpha$ is, the closer the process is to the linear state. One of the disadvantages of this filter is that the exact value of $\alpha$ is unclear. This problem does not interfere with the diagnosis of economic times and only changes the amount of deviation. So that if the mentioned parameter decreases or increases, then the value of the permanent and temporary trend will change, but definitely the sign of deviation from the trend (being positive or negative) will remain unchanged.

2.2.2. Analysis of Temporary and Permanent Shocks. The Blanchard-Quah technique has been used to analyze temporary and permanent shocks in oil revenues.

Using a bivariate VAR model (unemployment and production), Blanchard-Quah demonstrated how real GNP can be decomposed. In this method, the variables must be selected in such a way that both or at least one of them is unstable. Assume that the variable $z_{t}$ is stable and under the influence of shocks on $y_{t}$, we seek to analyze permanent and temporary $y_{t}$ shocks. Also, assuming no fixed component, the moving average of the two variables will be as follows:

$$
\begin{aligned}
\Delta y_{t} & =\sum_{k=0}^{\infty} c_{11}(k) \varepsilon_{1 t-k}+\sum_{k=0}^{\infty} c_{12}(k) \varepsilon_{2 t-k}, \\
z_{t} & =\sum_{k=0}^{\infty} c_{21}(k) \varepsilon_{1 t-k}+\sum_{k=0}^{\infty} c_{22}(k) \varepsilon_{2 t-k},
\end{aligned}
$$

or more briefly

$$
\left[\begin{array}{c}
\Delta y_{t} \\
z_{t}
\end{array}\right]=\left[\begin{array}{ll}
c_{11} & c_{12} \\
c_{21} & c_{22}
\end{array}\right]\left[\begin{array}{c}
\varepsilon_{1 t} \\
\varepsilon_{2 t}
\end{array}\right]
$$


where $\varepsilon_{1 t}, \varepsilon_{2 t}$ are usually known as white noise that the variance of both is constant.

Shocks are normalized if $\operatorname{var}\left(\varepsilon_{2 t}\right)=1$ and $\operatorname{var}\left(\varepsilon_{1 t}\right)=1$. In this case, $\sum \varepsilon$ is equal to

$$
\sum \mathcal{E}=\left[\begin{array}{cc}
\operatorname{var}\left(\varepsilon_{1 t}\right) & \operatorname{cov}\left(\varepsilon_{1 t}, \varepsilon_{2 t}\right) \\
\operatorname{cov}\left(\varepsilon_{1 t}, \varepsilon_{2 t}\right) & \operatorname{var}\left(\varepsilon_{2 t}\right)
\end{array}\right]=\left[\begin{array}{ll}
1 & 0 \\
0 & 1
\end{array}\right] .
$$

Long-term constraints are also defined as

$$
\sum_{k=0}^{\infty} c_{11}(k)=0
$$

The VAR pattern is estimated as

$$
\left[\begin{array}{c}
\Delta y_{t} \\
z_{t}
\end{array}\right]=\left[\begin{array}{cc}
A_{11}(L) & A_{12}(L) \\
A_{21}(L) & A_{22}(L)
\end{array}\right]\left[\begin{array}{c}
\Delta y_{t-1} \\
z_{t-1}
\end{array}\right]+\left[\begin{array}{c}
e_{1 t} \\
e_{2 t}
\end{array}\right] .
$$

The residues of the var model are a combination of residue $\varepsilon_{1 t}, \varepsilon_{2 t} . e_{1 t}$ is the error of predicting a future period $y_{t}$ written as in (9):

$$
e_{1 t}=\Delta y_{t}-E_{t-1} \Delta y_{t}
$$

Based on the moving average model, the forecast error of a future period is written as equation (10).

$$
c_{11}(0) \varepsilon_{1 t}+c_{12}(0) \varepsilon_{2 t} \text {. }
$$

Since the prediction errors in equation (10) are equal, we can write

$$
e_{1 t}=c_{11}(0) \varepsilon_{1 t}+c_{12}(0) \varepsilon_{2 t} .
$$

Similarly, since $e_{2 t}$ is the error of predicting a future period of $z_{t}$, we have

$$
e_{2 t}=c_{21}(0) \varepsilon_{1 t}+c_{22}(0) \varepsilon_{2 t} .
$$

By combining two equations (11) and (12), equation (13) will be obtained:

$$
\left[\begin{array}{l}
e_{1 t} \\
e_{2 t}
\end{array}\right]=\left[\begin{array}{ll}
c_{11}(0) & c_{12}(0) \\
c_{21}(0) & c_{22}(0)
\end{array}\right]\left[\begin{array}{l}
\varepsilon_{1 t} \\
\varepsilon_{2 t}
\end{array}\right]
$$

It will be possible to extract $\varepsilon_{1 t}$ and $\varepsilon_{2 t}$ from regression residues, that is, $e_{1 t}$ and $e_{2 t}$. Blanchard-Quah showed that the relationship between the variance matrix equation, covariance, the moving average model, and the long-run constraint creates four constraints on which the above four coefficients can be obtained. Using the residuals of the VAR model, estimates of $\operatorname{VAR}\left(e_{1}\right), \operatorname{VAR}\left(e_{2}\right)$, and $\operatorname{COV}\left(e_{1}, e_{2}\right)$ can be obtained.

\section{Econometric Methods}

In general classification of the variables affecting business cycles, we can refer to monetary, financial, and price variables. Real variables have a theoretical basis, such as real business and investment cycles. Monetary variables are supported by the Austrian views of business cycles, equilibrium theory, and monetary imbalances of business cycles. Financial variables are also confirmed by the theory of financial acceleration, and price variables are confirmed by the theories of later Keynesian business cycles. In this study, based on the study of Huseynov and Ahmadov [16], the variables of exchange rate, government expenditures, and oil revenues are used and the effect of these variables on the business cycle is examined. Accordingly, the factors affecting business cycles are in the form

$$
\text { Cycle }=f(\text { LRE, LG, LROIL). }
$$

The generalized form of equation (14) can be expressed as

$$
\text { Cycle }=f\left(\text { LRE, LG, } \operatorname{shock}_{T}, \operatorname{shock}_{P}\right),
$$

where the Cycle is business cycle, LRE is exchange rate logarithm, LG is government expenditure logarithm, LROIL is oil revenue logarithm, shock ${ }_{T}$ is permanent oil revenue shocks, and $\operatorname{shock}_{P}$ is temporary oil revenue shocks.

\section{Estimation of the Original Model and Analysis}

In order to extract business cycles, the trend size is first estimated from the logarithm of GDP at a fixed price (including oil) using the HP filter. Thus, fluctuation has been extracted around the course of the recession and boom period. So that if GDP is less than the filtered amount, there is a recession in that year, and if it is more, there is an economic boom in that year. The results of the HP filter for Iran are shown in the following Figure 1.

4.1. Separation of Temporary and Permanent Shocks of Oil Revenues. Using the Blanchard-Quah econometric technique, it is possible to extract each of the temporary and permanent shocks of oil revenues. In this method, two variables of business cycles and oil revenue have been used. Before estimating the pattern using the Blanchard-Quah method, the variables must be selected in such a way that both or at least one of them is nonstationary. Therefore, the generalized Dickey-Fuller test was used to examine the stationary of the variables. All variables are nonstationary except oil revenues, which are stationary after the first-order difference. The results of the stationary test are shown in Table 1. In this study, considering the Akaike information criterion (AIC) and Hannan-Quinn (HQ) criteria, the optimal number of lag orders is considered to be two.

The important point in analyzing oil revenue shocks into temporary and permanent components is that oil revenue shocks should not have a long-term impact on business cycles. The Johansen method has been used to investigate the existence of a cumulative relationship between variables. According to the test statistics, the existence of an integration vector is not confirmed. After determining the lack of cointegration vectors, we have to estimate a two-variable VAR model and then derive the structural model coefficients by applying short-term and long-term constraints. The results of estimating the VAR model are presented in Table 2.

Based on the Blanchard-Quah method, we have analyzed the permanent and temporary shocks from the VAR estimation. The analysis results are shown in Table 3. We 


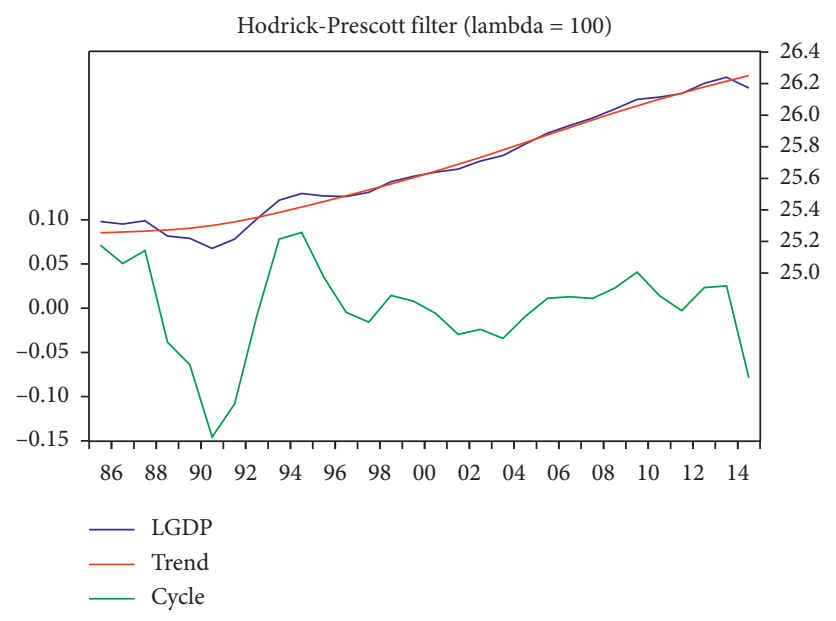

Figure 1: Business cycle extraction.

TABLE 1: Summary of the unit root test result.

\begin{tabular}{|c|c|c|c|c|}
\hline \multirow{2}{*}{ Variables } & \multicolumn{2}{|c|}{ At level } & \multicolumn{2}{|c|}{ First-order difference } \\
\hline & $\mathrm{ADF}$ test stat & Order of integration & ADF test stat & Order of integration \\
\hline CYCLE & -2.412 & - & -4.667 & $\mathrm{I}(1)$ \\
\hline LRE & -2.594 & - & -3.756 & $\mathrm{I}(1)$ \\
\hline LG & -1.387 & - & -3.942 & $\mathrm{I}(1)$ \\
\hline LROIL & $-3.294^{*}$ & - & -4.651 & $\mathrm{I}(1)$ \\
\hline $\mathrm{SHOCK}_{T}$ & -1.814 & - & -3.397 & $\mathrm{I}(1)$ \\
\hline $\mathrm{SHOCK}_{P}$ & -1.263 & - & -3.681 & $\mathrm{I}(1)$ \\
\hline Note: & \multicolumn{2}{|c|}{$\begin{array}{c}\text { Critical value } \\
1 \%=-3.736 \\
5 \%=-2.988 \\
10 \%=-2.634\end{array}$} & \multicolumn{2}{|c|}{$\begin{array}{c}\text { Critical value: } \\
1 \%=-3.737 \\
5 \%=-2.990 \\
10 \%=-2.635\end{array}$} \\
\hline
\end{tabular}

TABLE 2: Vector autoregressive model results.

\begin{tabular}{lcc}
\hline Variables & Cycle & LROIL \\
\hline Cycle $(-1)$ & $1.0839(0.2021)[5.3633]$ & $-2.2836(1.8015)[-1.2676]$ \\
Cycle $(-2)$ & $-0.7982(0.2114)[3.7745]$ & $1.2491-(1.8852)[-0.6626]$ \\
LROIL $(-1)$ & $0.0447-(0.0245)[-1.8216]$ & $0.8133(0.2192)[3.7105]$ \\
LROIL (-2) & $0.0539(0.0270)[1.9967]$ & $0.2585(0.2409)[1.0733]$ \\
$C$ & $0.1007-(0.1237)[-0.8145]$ & $0.7167-(1.1028)[-0.6499]$ \\
$R^{2}$ & 0.5988 & 0.8548 \\
\hline
\end{tabular}

hypothesized that there are two types of shocks in the economy. The first type is temporary shocks that have no long-term effect on business cycles and oil revenues, and the second type is permanent shocks that have a long-term effect on business cycles but have no effect on oil revenues. With these assumptions, time series can be obtained for each type of shock.

According to Table 4, the temporary shock with a value of (96.64) in the first period had the largest share in the fluctuations of Iran's business cycles, while the constant momentum in the eighth period with the amount of (25.39) had the largest share in the fluctuations of Iran's business cycles. As the results in Table 4 show, the main cause of business cycle fluctuations is temporary shocks to oil revenues, so that, in all periods, temporary shocks to oil revenues have had the largest share in explaining the fluctuations of business cycles. For example, in the first period, temporary shocks to oil revenues explain about $97 \%$ of the changes, while permanent shocks explain about $3 \%$, and in later periods, this share changes.

4.2. Investigating the Effect of Structural Shocks. Figure 2 represents the continuous shocks of oil revenues by a standard deviation on the fluctuations of business cycles, so that until the second period, the changes of business cycles in response to the permanent shocks of oil revenues are a decreasing trend. From the second to the fifth period, it has an upward trend and then has a vacillatory behavior. Figure 3 represents the effect of temporary shocks to oil revenues on trade cycle fluctuations with a standard deviation. At the moment of temporary shocks to oil revenues, 
TABLE 3: Structural vector autoregressive (SVAR) model results.

Structural VAR estimates

Sample (adjusted): 19852019

Included observations: 34 after adjustments

Estimation method: method of scoring (analytic) derivatives

Convergence achieved after 7 Iterations

Structural VAR is just-identified

Model: $\mathrm{Ae}=\mathrm{Bu}$ where $E\left[\mathrm{uu}^{\prime}\right]=\mathrm{I}$

Restriction type: long-run text form

Long-run response pattern

$C(1) C(2)$

$0 C(3)$

$C(1)$

$C(2)$

$C(3)$

Log likelihood: 49.15211

Estimated $A$ matrix

1.0000000 .000000

0.0000001 .000000

Estimated $B$ matrix

$0.034459-0.006424$

0.1704190 .261892

$\begin{array}{cc}\text { Coefficient } & \text { Std. error } \\ -0.048239 & 0.006446 \\ 0.150716 & 0.022107 \\ 11.04005 & 1.475289\end{array}$

Coefficient

11.04005
1.475289 $z$-statistic
-7.483315
6.817450
7.483315

Prob.

0.0000

0.0000

0.0000 the fluctuations of trade cycles reach their maximum value (0.39). Over time, the effect of the shocks decreases and reaches its lowest value in the fifth period. From the fifth to the eighth period, it has an upward trend and from the eighth period onwards, it has a downward trend.

Figure 4 represents the relationship between the constant shocks of oil revenue and the logarithm of oil revenue. With the constant shocks of oil revenues, the logarithm of oil revenues decreases, but after two periods, it has an increasing trend. Figure 5 represents the relationship between temporary shocks to oil revenue and the logarithm of oil revenue. With the occurrence of temporary shocks in oil revenue, the logarithm of oil revenue decreases, and from the third period onwards, it has a sinusoidal trend that, in the tenth period, the effect of temporary shocks of oil revenue on its logarithm reaches zero.

4.3. Autoregressive Distributed Lag (ARDL). Because the variables used in the model are a combination of variables $I(0)$ and $I(1)$. Therefore, the ARDL approach is used to estimate the short-term and long-term effects between pattern variables. In the present study, according to the period under study, the Schwartz-Bayesian criterion is used as a saving criterion that selects the shortest possible interval length so that a large degree of freedom is not lost. The optimal interval 2 is selected for the model. The Brush-Godfrey autocorrelation test shows no serial correlation between wastes. To check the variance of heterogeneity, Breusch-Pagan-Godfrey test was performed. The value of the F-statistic in this method is 1.370909 which does not reject the null hypothesis based on homology variance. The results for estimating the dynamic ARDL pattern are presented in Table 5.

According to the presented results, the logarithm variables of government expenditures, permanent shocks of oil revenues and temporary shocks of oil revenues, and its first interruption are among the variables that have a negative effect on the flow of business cycles in the short term and the logarithm variable of exchange rate has a positive effect. All variables are statistically significant at the 95\% level. After estimating the dynamic equation, the test for the presence or absence of a long-run equilibrium relation must be performed. For this purpose, the band test has been used and the results of this test indicate the existence of a long-term equilibrium relationship. Now, the existence of a long-run equilibrium relationship in the model is confirmed, the longterm pattern can be estimated. The results related to the estimation of this model are reported in Table 6.

The estimated business cycle function in the long run is given in equation (16):

$$
\begin{aligned}
\text { CYCLE }= & -0.4309 \mathrm{LG}+0.0403 \mathrm{LRE} \\
& -106.1351 \operatorname{shock}_{P}-67.8037 \operatorname{shock}_{T}+1.3402 .
\end{aligned}
$$

4.4. Effect of Government Expenditure Logarithm. The logarithm variable of government spending in the Iranian economy has a negative effect on the formation of business cycles, so that increasing government spending leads the economy to recession because increasing government spending reduces private investment in the country. However, this variable has mainly played an inflationary role in the Iranian economy. It is expected that the control and management of this variable in Iran can have a significant impact on the movement of business cycles.

4.5. Effect of Exchange Rate Logarithm. The exchange rate variable is directly related to business cycles; that is, with the increase of the exchange rate, the economy moves towards prosperity, and with its decrease, it moves towards recession. 
TABle 4: Percentage of fluctuations in the variance of business cycles.

\begin{tabular}{lcc}
\hline Period & The share of temporary shocks & The share of permanent shocks \\
\hline 1 & 96.6415 & 3.3584 \\
2 & 84.1234 & 16.3408 \\
3 & 80.9681 & 19.0318 \\
4 & 81.2936 & 18.7063 \\
5 & 79.5345 & 20.4654 \\
6 & 76.4169 & 23.5830 \\
7 & 74.6943 & 25.3057 \\
8 & 74.6048 & 25.3952 \\
9 & 74.9374 & 25.0625 \\
10 & 75.0641 & 24.9358 \\
\hline
\end{tabular}

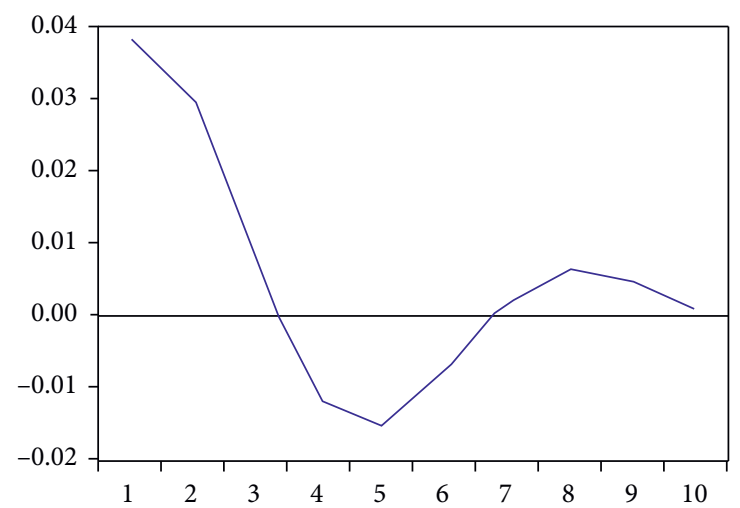

FIgURE 2: The response of the business cycles to temporary shocks in oil revenues.

The justification for this relationship is that the increase in the exchange rate makes imports more expensive and nonoil exports cheaper, reduces the country's imports, and increases its exports. On the other hand, with the increase in the price of imported goods, the power of the domestic producer to compete with the foreign producer increases. Therefore, an increase in the exchange rate can have a positive effect on the flow of trade in Iran.

4.6. The Effect of Permanent and Temporary Shocks of Oil Revenue. Permanent and temporary shocks in oil revenues have a negative effect on the flow of trade cycles, meaning that increasing permanent and temporary shocks in oil revenues move the economy towards recession. The justification for this is that the increase in permanent and temporary shocks of oil revenues reduces GDP, increases unemployment, and reduces investment in the country. On the other hand, one of the characteristics of oil economies (such as Iran) is the presence of Dutch disease in these economies. As oil prices and oil revenues rise, a country's wealth increases, increasing wealth strengthens and grows the nontradable sector of the economy and weakens the tradable sector of the economy. In this case, activities such as services and construction sector grow and instead activities such as industry sector stagnate.

Since severe global economic downturns will have a negative effect on the Iranian economy, which relies on oil revenues. Therefore, identifying the trade fluctuations of oil- consuming countries and affecting the global economy can help predict the occurrence of future crises and take the necessary measures before its occurrence to reduce its negative effects.

4.7. Synchronization of Business Cycles. In this section, the results of estimating the business cycle synchronization index are reviewed. Table 7 shows the concurrence of Iran's business cycles with selected OECD countries.

The results of estimating the business cycles synchronization index presented in Table 7 show that Belgium, Germany, Greece, Japan, Spain, and Turkey have had business cycles synchronization with Iran, But other countries have shown that trade cycles do not coincide with Iran. With a correlation coefficient of 0.42 , Germany has the highest synchronization of business cycles with Iran.

\section{Discussion}

Since the most important goal of economists is to prevent economic fluctuations and planning in an economy without understanding how to create business cycles makes no sense, there is a fundamental need to examine business cycles. It is also important to be aware of the impact of oil shocks on business cycles in order to select appropriate policies to prevent the devastating effects of these shocks in countries with oil-dependent economies. The results of the present study show that the main cause of business cycle fluctuations 


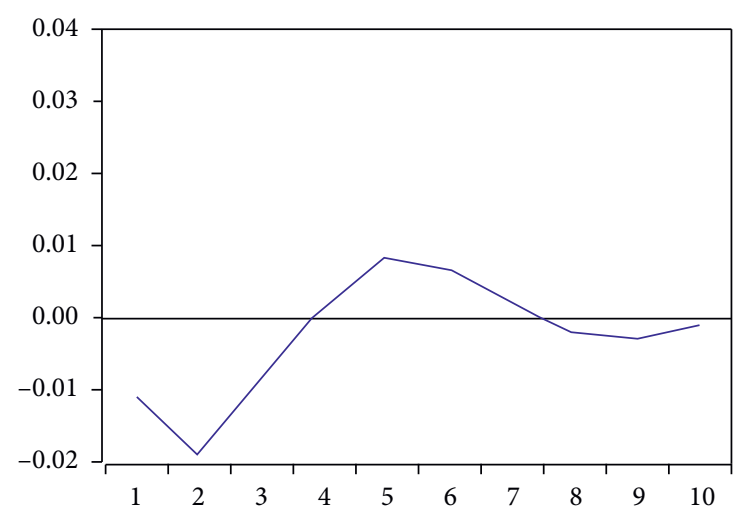

FIgURE 3: The response of the business cycles to persistent shocks in oil revenues.

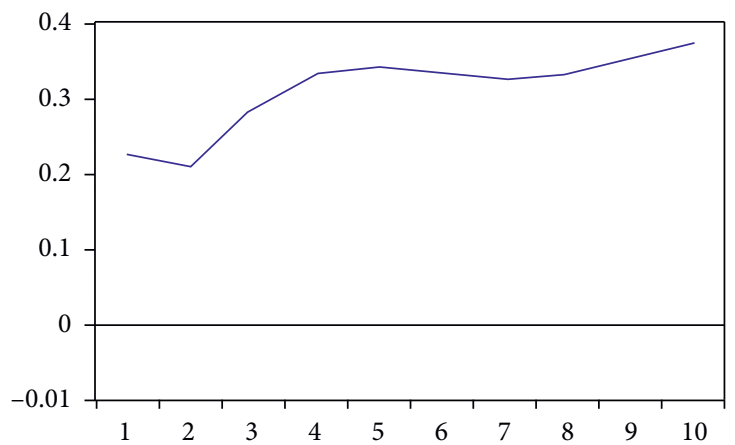

Figure 4: The response of the oil revenue logarithm to the constant shocks of oil revenue.

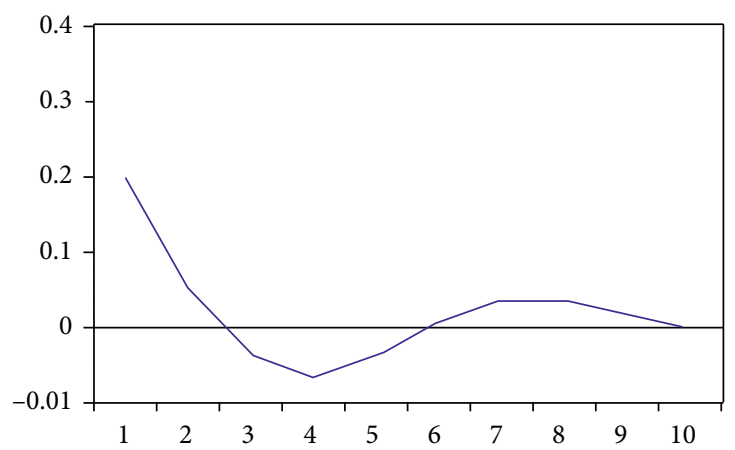

FIgURE 5: The response of the oil revenue logarithm to temporary shocks.

is temporary shocks in oil revenues and have the greatest impact on business cycle fluctuations. This study is important for countries with oil-dependent economies because they often face problems such as inflation and budget deficits. Obviously, recognizing the key factors that create these business cycles can help economic planners and policymakers in the country to make more accurate and efficient decisions.

The results of examining business cycles in China show that productivity growth is the main cause of economic fluctuations [18]. A simultaneous study of trade cycles and inflation targeting in the Asian Monetary Union shows that inflation targeting leads to an increase in the synchronization of trade cycles [19]. Examining the cause of the emergence of trade cycles among the G7 countries shows that monetary policy has a great impact on trade cycles [20]. The impact of oil price shocks in the Philippines showed that negative oil price shocks lead to a continuous decline in real GDP and falling oil prices have a greater role in the fluctuations of variables than rising oil prices [21].

So the source of business cycles is different. But oil price shocks are the dominant shocks in the world that connect the economies of different countries. As this issue becomes clear, the economic planners of oil-dependent countries must adopt appropriate policies to deal with the positive shocks of oil prices during the boom compared to the 
TABLE 5: Short-term estimation results: $\operatorname{ARDL}(1,0,0,0,1)$.

\begin{tabular}{lccr}
\hline Variables & Coefficients & $t$-statistic & Prob \\
\hline CYCLE $(-1)$ & 0.3444 & 1.6953 & 0.1041 \\
LG & -0.2824 & -2.9545 & 0.0073 \\
LRE & 0.02642 & 2.3044 & 0.0310 \\
SHOCKP & -69.5772 & -2.5509 & 0.0182 \\
SHOCKT & -19.7234 & -2.1890 & 0.0395 \\
SHOCKT $(-1)$ & -24.7256 & -2.4926 & 0.0207 \\
C & 0.8785 & 2.8838 & 0.0086 \\
\hline
\end{tabular}

TABLE 6: Long-term estimation results: $\operatorname{ARDL}(1,0,0,0,1)$.

\begin{tabular}{lccc}
\hline Variables & Coefficients & $t$-statistic & Prob \\
\hline LG & -0.4309 & -2.5410 & 0.018 \\
LRE & 0.0403 & 2.3068 & 0.030 \\
SHOCKP & -106.1351 & -2.2700 & 0.033 \\
SHOCKT & -67.8037 & -2.1399 & 0.043 \\
C & 1.3402 & 2.4270 & 0.023 \\
\hline
\end{tabular}

TABLE 7: Estimation of business cycle synchronization index.

\begin{tabular}{lr}
\hline Countries & Business cycle correlation coefficient \\
\hline Belgium & 0.09 \\
China & 0.30 \\
France & 0.00 \\
Germany & 0.042 \\
Greece & 0.29 \\
India & -0.15 \\
Italy & -0.07 \\
Japan & 0.17 \\
South Korea & -0.10 \\
Spain & 0.10 \\
Turkey & 0.03 \\
England & -0.44 \\
\hline
\end{tabular}

recession. Also, during the recession, due to the strong dependence of the economy on oil revenues, positive oil price shocks are able to provide a way out of the recession and transition to the boom period. The results of this study indicate the vulnerability of the Iranian economy to exogenous oil price shocks. Therefore, in order to reduce the vulnerability of long-term growth to fluctuations in oil revenues, policymakers and economic planners of the country are advised to make the necessary measures to reduce the dependence of the Iranian economy on oil revenues in the forefront of their plans.

\section{Conclusion}

Among the factors of instability in oil-dependent economies are oil revenues and the resulting shocks. Due to the reliance of the economies of oil-exporting countries on oil production and revenues from oil sales, oil market developments and the resulting shocks can also explain some of the fluctuations in business cycles. Given that it is necessary to be aware of the impact of oil shocks on business cycles in order to select appropriate policies to prevent the destructive effects of these shocks in oilexporting countries that have an oil-dependent economy, including Iran, in this study, the effect of permanent and temporary oil revenue shocks on business cycles was investigated. Accordingly, temporary and permanent shocks of oil revenue are extracted using the BlanchardQuah technique. The results of the Blanchard-Quah technique show that the main cause of fluctuations in business cycles is temporary shocks to oil revenues, so that, in all periods, temporary shocks in oil revenues have had the largest share in explaining the fluctuations of business cycles. The results obtained from the ARDL method show that the variables of government expenditures and permanent and temporary shocks of oil revenues in the short and long-term model have a negative effect on business cycles, and the exchange rate variable has a positive effect on business cycles. Finally, the estimation of the trade cycle synchronization index shows that Belgium, Germany, Greece, Japan, Spain, and Turkey have had trade cycle synchronization with Iran, and Germany has the highest synchronization of trade cycles with Iran with a correlation coefficient of 0.42 . 
6.1. Policy Recommendations. According to the results of this study, the following are recommended:

(1) Countries whose economy is dependent on oil revenues should reduce dependence on oil revenues by increasing the empowerment of the manufacturing sector along with improving the tax system in order to make revenues and public budgets dependent on the economy to reduce oil revenues.

(2) Take more care on the proper functioning of the foreign exchange reserve account and the National Development Fund to prevent shocks to the national economy due to global oil price fluctuations and a sudden drop in foreign exchange earnings of countries whose economies rely on oil revenues.

(3) Considering that, in any economic system, policymakers seek to extend the period of economic prosperity and, consequently, tend to limit the period of recession. The study showed that oil revenue shocks pushed the economy into recession. Accordingly, due to the existence of business cycles, although it is inevitable, it is suggested that, in order to reduce the economy's dependence on oil and thus reduce its vulnerability, reform policies should be implemented, including foreign exchange and fiscal policies.

\subsection{Suggested Topics for Future Studies}

(1) Investigating the effect of trade cycles on the financial markets of oil-exporting countries and OECD countries.

(2) Investigating the effect of oil pricing and sales share in oil-exporting countries on the trade cycles of oilimporting countries.

(3) Consequences of implementing joint international and regional economic policies between oilexporting countries and oil-importing countries, considering the simultaneous effect of trade cycles.

\section{Data Availability}

The data used to support the findings of this study are available from the corresponding author upon request.

\section{Conflicts of Interest}

The authors declare that they have no conflicts of interest.

\section{References}

[1] W. C. Mitchell, Business Cycles, vol. 3, University of California Press, Berkeley, CA, USA, 1913.

[2] J. B. Long Jr. and C. I. Plosser, "Real business cycles," Journal of Political Economy, vol. 91, no. 1, pp. 39-69, 1983.

[3] R. E. Lucas, "Understanding business cycles," Essential Readings in Economics, Palgrave, London, UK, pp. 306-327, 1995.

[4] C. F. Dornbush, G. B. Robinson, and E. J. Cornelia, "System for implementing collaborative training and online learning over a computer network and related techniques," U.S. Patent No. 6, 2002.

[5] J. D. Hamilton, "A new approach to the economic analysis of nonstationary time series and the business cycle," Econometrica: Journal of the Econometric Society, vol. 57, no. 2, pp. 357-384, 1989.

[6] F. E. Kydland and E. C. Prescott, "Business cycles: real facts and a monetary myth," Federal Reserve Bank of Minneapolis Quarterly Review, vol. 14, no. 2, pp. 3-18, 1990.

[7] C. E. Alper, "Nominal stylized facts of Turkish business cycles," METU Studies in Development, vol. 25, no. 2, pp. 233-244, 1998.

[8] J. H. Stock and M. W. Watson, "Diffusion indexes,"NBER working paper w6702, p. 1998, 1998.

[9] P. B. Rana, "Economic integration and synchronization of business cycles in East Asia," Journal of Asian Economics, vol. 18, no. 5, pp. 711-725, 2007.

[10] X.-L. Wang, C. Qin, E.-B. Wang et al., "Interlocked and interdigitated architectures from self-assembly of long flexible ligands and cadmium salts," Angewandte Chemie, vol. 116, no. 38, pp. 5146-5150, 2004.

[11] R. Inklaar, R. Jong-A-Pin, and J. De Haan, "Trade and business cycle synchronization in OECD countries-a reexamination," European Economic Review, vol. 52, pp. 646666, 2008.

[12] O. Mendoza and D. Vera, "The asymmetric effects of oil shocks on an oil-exporting economy," Cuadernos de economía, vol. 47, no. 135 , pp. 3-13, 2010.

[13] K. A. Mork, "Oil and the macroeconomy when prices go up and down: an extension of Hamilton's results," Journal of Political Economy, vol. 97, no. 3, pp. 740-744, 1989.

[14] C.-C. Hsu, J.-Y. Wu, and R. Yau, "Foreign direct investment and business cycle co-movements: the panel data evidence," Journal of Macroeconomics, vol. 33, no. 4, pp. 770-783, 2011.

[15] M. Jahadi and Z. Elmi, "Oil price shocks and economic growth evidence from OPEC," Quarterly Journal of Economic Growth and Development Research, vol. 1, no. 2, pp. 40-11, 2011.

[16] S. Huseynov and V. Ahmadov, "Business cycles in oil exporting countries: a declining role for oil?. No. 03/2014," Essential Readings in Economics, Graduate Institute of International and Development Studies Working Paper, 2014.

[17] J. W. Fedderke and D. K. Mengisteab, "Estimating South Africa's output gap and potential growth rate," South African Journal of Economics, vol. 85, no. 2, pp. 161-177, 2017.

[18] M. Zhao and M. Hsu, "China's real business cycles and fiscal policies between 1954-2004: productivity and policy changes," National Graduate Institute for Policy Studies (GRIPS), Tokyo, Japan, Working Paper, 2008.

[19] A. K. Rose, "Understanding business cycle synchronization: is inflation targeting paving the way to Asian Monetary Union?," in Costs and Benefits of Economic Integration in Asia 2011, R. J. Barro and J.-W. Lee, Eds., pp. 89-125, Oxford University Press, Oxford, UK, 2009.

[20] F. Canova and G. De Nicolo, "Monetary disturbances matter for business fluctuations in the G-7," Journal of Monetary Economics, vol. 49, no. 6, pp. 1131-1159, 2002.

[21] C. E. Raguindin and R. G. Reyes, The Effects of Oil Price Shocks on the Philippine Economy: A VAR Approach, University of the Philippines School of Economics, Quezon City, Philippines, 2005. 